Kumarasiri, D.M.G.B.T. and Dissanayake, D.M.P.P., 2019. Stakeholders' involvement in successful implementation of waste to energy projects: Case studies in Sri Lanka. In: Sandanayake, Y.G., Gunatilake, S. and Waidyasekara, A. (eds). Proceedings of the $8^{\text {th }}$ World Construction Symposium, Colombo, Sri Lanka, 8-10 November 2019, pp. 535-546. DOI: doi.org/10.31705/WCS.2019.53. Available at: https://2019.ciobwcs.com/papers

\title{
STAKEHOLDERS' INVOLVEMENT IN SUCCESSFUL IMPLEMENTATION OF WASTE TO ENERGY PROJECTS: CASE STUDIES IN SRI LANKA
}

\author{
D.M.G.B.T. Kumarasiri ${ }^{1}$ and D.M.P.P. Dissanayake ${ }^{2}$
}

\begin{abstract}
Same as to many countries, Sri Lanka is also facing a waste crisis due to the issues in municipal solid waste management. As a solution, Waste to Energy (WtE) concept was aroused, which transforms waste to energy in the form of electricity. Although it was a successful strategy for many of the countries, in Sri Lanka, most of the instances, WtE projects were resulted in failures due to issues provoke in the implementation. Poor stakeholder management has been one of the key contributing issues behind these failures. Hence, there is a timely need of identifying key stakeholders and their role to pledge project success. Despite the abundance of research on WtE projects, a gap in literature could be identified, when it comes to exploring stakeholders' involvement in successful implementation of WtE projects in Sri Lanka. Thus, this study is aimed at bridging this knowledge gap. A qualitative research approach with two case studies were used in this study. A total of 12 interviews were conducted and collected data were analysed using content analysis. The empirical findings revealed that government, community, central environmental authority, engineering procurement and construction contractors, municipal council and central electricity board are the most influential stakeholders involved in the implementation of WtE projects. Although their level of contribution is varied to each other, all stakeholders along with their interests and involvement collectively thrive to assure the successful implementation of WtE projects in Sri Lanka. The knowledge generated through this research can be used by respective industry practitioners in Sri Lanka in implementing future WtE projects successfully.
\end{abstract}

Keywords: Implementation Process; Municipal Solid Waste Management (MSWM); Stakeholders; Waste to Energy (WtE).

\section{INTRODUCTION}

Due to the rapid growth in the population, booms in the economy, rapid urbanisation, and the rise in the consumer choices, the Municipal Solid Waste (MSW) generated in mass levels in almost all the countries in the world (Palanivel and Sulaiman, 2014). It was estimated that the current global MSW generation levels are nearly 1.3 billion tonnes per annum and expected that, it will be increased up to 2.2 billion tonnes annually at the end of the year 2025 (Hoornweg and Bhada, 2012). Concequently, MSW generation has led to different adverse environmental impacts, public health risks (Ramachandra et al.

\footnotetext{
${ }^{1}$ Department of Building Economics, University of Moratuwa, Sri Lanka, binashikumarasiri@gmail.com

2 Department of Building Economics, University of Moratuwa, Sri Lanka, piumid@uom.lk
} 
2018). Ogawa (2000) reported, this is due to the low and irregular collection coverage, crude open dumping, no water and air pollution control in burning waste and handling of informal scavenging activities. Compared to developed countries, developing countries have to respond to these new challenges, and in recent times, WtE has been increasingly viewed as a solution to the problems derived from rising waste quantities in expanding cities as well as rapidly growing energy demand (Kothari et al. 2010; Energy Information Administration, 2017). However, $\mathrm{WtE}$ can never resolve the problem alone, but rather requirements to be entrenched in an integrated solid waste management system that relates to the specific local conditions with regards to waste composition, environmental challenges, informal sector, resource prices, financing, and other aspects.

There are certain key stakeholders that appear throughout the implementation of WtE projects (Contreras et al. 2008). Identification of such stakeholders, their interests and role in a WtE project is vital to assure the project success (Soltani et al. 2015). These stakeholders must be involved openly and actively (The World Bank, 1999), and should be consulted throughout the project phases. In Sri Lanka, although six (6) projects are being proposed to implement locally, only two of them have been implemented yet, two projects were failed already and implementation of rest of the projects have been adjourned (Priyalal, 2017). It has been discovered that poor stakeholder management has been one of the key contributing issues behind the failure of WtE projects in Sri Lanka. In this context, a timely need has been emerged in identifying the key stakeholders who are involved in implementation of $\mathrm{WtE}$ projects and their role to pledge project success. Despite the abundance of research on solid waste management, the stakeholders' involvement in successful implementation of WtE projects in Sri Lanka has not being researched yet. Thus, having identified the knowledge gap, this paper aimed to investigate the key stakeholders and their involvement stakeholders' in different phases WtE projects to ensure the success of upcoming projects.

\section{LITERATURE REVIEW}

Following sub sections explore the relevant literature in the research arena with major focus on the concept of WtE and its applicability and stakeholders involved in successful implementation of $\mathrm{WtE}$ projects.

\subsection{THE CONCEPT OF WTE AND ITS APPLICABILITY}

WtE technology can be defined as a process of recovering energy from waste by treating them, in the form of electricity, transport fuels or heat (Keunecke, 2016; Breeze, 2018). Moreover, a study conducted in China emphasised that WtE is the generation of energy from the waste directly through the methods of combustion such as gasification, incineration and pyrolysis or the production of hydrogen, methane and some other synthetic fuels through anaerobic digestion or through mechanical biological treatment methods, landfill gas utilization and bio refineries (Moya et al. 2017). According to Themelis and Ulloa (2007), by the year of 2013, the global market of WtE was valued about US dollars 25.32 billion and energy through thermal conversion technologies lead the global market which accounted as $88.2 \%$ of the total revenue of WtE market in 2013. Further, Schiffer et al. (2016) explained that Europe has the most demanding and sophisticated market for the $\mathrm{WtE}$, which is $47.6 \%$ of the total WtE market. WtE market of China has the fastest growth rate and it was expected that it will be doubled its capacity of WtE within the period of 2011-2025. Moreover, they identified that among WtE 
treatment technologies, biological treatment is having the most potential growth rate which will be commercially viable. As the regional perspective Asia-Pacific will remark the highest growth rate (Schiffer et al. 2016). Developed countries such as Sweden, Germany, Netherlands, United Kingdom, Denmark etc. have already implemented WtE plants (Rawlins et al. 2014). Similarly, it is estimated that about 130 million tonnes of MSW are combusted annually in over $600 \mathrm{WtE}$ facilities worldwide (Themelis and Ulloa, 2007). Benefits that can be gained from WtE plants includes reduction of waste volume, reduction of land demand compared to landfilling options, reduction of environmental and social externalities attributed to waste disposal and creation of job opportunities (Rawlins et al. 2014). Sri Lanka is also currently looking forward to use WtE technologies. The recent study by Priyalal (2017) identified six (6) mega WtE projects, which were proposed for supplying electricity to the grid. According to the researcher, two (02) of them have been implemented using the WtE methods such as incineration, gasification and anaerobic digestion. Not only these WtE methods, but also Sri Lanka has the capacity to use other latest methods such as pyrolysis, plasma technology as revealed by Priyalal (2017).

\subsection{STAKEHOLDERS INVOLVED IN SUCCESSFUL IMPLEMENTATION OF WTE PROJECTS}

Stakeholders are any individual or any group of people who are having a high impact to an organisation who can affect or affected by the achievement of organisations goals and objectives ( $\mathrm{Li}$ et al. 2013). Hence, for the WtE projects, the involvement of stakeholders could affect critically since they are playing an important role in the design, implementation, and promotion of $\mathrm{WtE}$ projects (Contreras et al. 2008). Table 1 summarises the different types of stakeholders who are involved in a WtE project and their role in the project. This was based on the previous studies, which have been conducted by many researchers in the same area.

Table 1: Summary of stakeholder involvement

\begin{tabular}{|c|c|}
\hline Stakeholder & Role/Interests \\
\hline \multirow{3}{*}{$\begin{array}{l}\text { Regulatory } \\
\text { stakeholders } \\
\text { (Government/ } \\
\text { Municipalities) }\end{array}$} & $\begin{array}{l}\text { Have the centralised power for selection of MSWM strategies and } \\
\text { implementing them }\end{array}$ \\
\hline & $\begin{array}{l}\text { The Municipalities are sentient of human health dangers and } \\
\text { environmental impacts associated with WtE projects }\end{array}$ \\
\hline & $\begin{array}{l}\text { They have the direct control to decide whether the project will proceed } \\
\text { or not, they have the power to see whether the project is in accordance } \\
\text { with the pre-stated requirements }\end{array}$ \\
\hline \multirow{3}{*}{$\begin{array}{l}\text { Industrial Experts } \\
\text { (Research } \\
\text { institutions) }\end{array}$} & Working with the government to undertake studies on WtE \\
\hline & Have widespread of information on WtE technologies \\
\hline & $\begin{array}{l}\text { They focused on the vulnerable population needs and communicate them } \\
\text { to wider audience which includes policy makers, managers and planners }\end{array}$ \\
\hline $\begin{array}{l}\text { Community and } \\
\text { other Influencing }\end{array}$ & $\begin{array}{l}\text { Cannot directly influence to the project but can be indirectly influenced } \\
\text { to it. }\end{array}$ \\
\hline $\begin{array}{l}\text { Stakeholders } \\
\text { (Residents living } \\
\text { near to the site, } \\
\text { and media) }\end{array}$ & $\begin{array}{l}\text { If the media leads towards the opposition, it will be difficult to get a } \\
\text { positive attitude from the population. }\end{array}$ \\
\hline
\end{tabular}




\begin{tabular}{|c|c|}
\hline Stakeholder & Role/Interests \\
\hline & $\begin{array}{l}\text { They can be influenced to the } \mathrm{WtE} \text { project by source reduction and } \\
\text { cooperating with civil bodies in the identification of the site for the } \mathrm{WtE} \\
\text { facilities }\end{array}$ \\
\hline & $\begin{array}{l}\text { Concern about the project due to the impacts that could be occurs such } \\
\text { as noise, visual, traffic, etc. causing terminations, delays and change of } \\
\text { project }\end{array}$ \\
\hline \multirow[t]{2}{*}{$\begin{array}{l}\text { Private } \\
\text { organisations }\end{array}$} & $\begin{array}{l}\text { Searching and implementing appropriate actions to establish WtE plants, } \\
\text { they are providing required funds }\end{array}$ \\
\hline & $\begin{array}{l}\text { WtE projects are PPP (Private- Public partnerships) projects by which } \\
\text { Government is providing funds and private companies are engaged in } \\
\text { construction and implementation of the project }\end{array}$ \\
\hline $\begin{array}{l}\text { Environmental } \\
\text { regulators }\end{array}$ & $\begin{array}{l}\text { Establishing environmental standards and regulations, monitoring and } \\
\text { implementation Interested in the project to have a reduced environmental } \\
\text { impact of waste management. }\end{array}$ \\
\hline $\begin{array}{l}\text { Collection and } \\
\text { transportation } \\
\text { companies }\end{array}$ & $\begin{array}{l}\text { Interested towards the } \mathrm{WtE} \text { projects to maintain or enlarge the business } \\
\text { and there will be new requirements for sorting methods, containers, and } \\
\text { transportation vehicles if there are } \mathrm{WtE} \text { facilities }\end{array}$ \\
\hline Energy producers & $\begin{array}{l}\text { Imply oppositions to purchase of energy from external producers } \\
\text { Barriers to sell energy at local electricity rates }\end{array}$ \\
\hline
\end{tabular}

However, when it comes to Sri Lankan context, involvement of such stakeholders, their role in WtE Projects have not been discussed in literature yet. Thus, in bridging this knowledge gap, this paper intends to discuss the role of stakeholders in the WtE projects throughout its project phases. The next section discussed the research process adopted in bridging this knowledge gap.

\section{RESEARCH METHODOLOGY}

Yin (2014) suggested that a research approach has to be selected based on the type of research question, the extent of control an investigator has over actual behavioural events, and the degree of focus on contemporary or historical events. Since, this study followed an in-depth investigation on contemporary phenomenon (i.e. investigating stakeholders' involvement in successful implementation of WtE project) within its real-world context, with a 'how' type of research question (i.e. how could different types of stakeholders be involved in a WtE project?), case study research strategy could be justified. Currently, only two mega projects have been initiated and implemented in Sri Lanka. Therefore, both projects were selected as the cases considering 'stakeholders in a WtE mega project' as the unit of analysis. Both cases are similar in context, expecting literal replications. Table 2 gives a brief description of the selected two (02) cases.

A total of 12 interviews were conducted from both cases. Table 3 provides the profile of interviewees.

Further, both within-case analysis and cross-case analysis were done using code-based content analysis during the data analysis process. A pattern-matching (Yin, 2014) effort is presented in the discussion in Section 5 for theoretical generalisation purposes. 
Table 2: Description of two cases

\begin{tabular}{|c|c|c|}
\hline Criteria & Case A & Case B \\
\hline Project Commencement date & August 2017 & October 2017 \\
\hline Project End Date & August 2039 & October 2039 \\
\hline $\begin{array}{l}\text { Type of WtE technique } \\
\text { adapted }\end{array}$ & $\begin{array}{l}\text { Moving grate } \\
\text { incineration }\end{array}$ & $\begin{array}{l}\text { Hybrid plant }- \text { Anaerobic digestion } \\
\text { mass burn incineration/ }\end{array}$ \\
\hline $\begin{array}{l}\text { Approximate amount of } \\
\text { MSW utilized }\end{array}$ & 800 tons per day & $\begin{array}{l}\text { Anaerobic digestion - } 120 \text { tons per } \\
\text { day and Mass burn incineration - } \\
500 \text { tons per day }\end{array}$ \\
\hline $\begin{array}{l}\text { Approximate units of } \\
\text { electricity generated }\end{array}$ & $10 \mathrm{MW}$ & $12 \mathrm{MW}$ \\
\hline Project cost & 1300 million & 1400 million \\
\hline Status & Work in progress & Work in progress \\
\hline
\end{tabular}

Table 3: The profile of interviewees

\begin{tabular}{lll}
\hline Case & \multicolumn{1}{c}{ Designation } & \multicolumn{1}{c}{ Role } \\
\hline Case A & $\begin{array}{l}\text { Managing Director } \\
\text { Deputy Project Director } \\
\text { Assistant manager -renewable } \\
\text { energy }\end{array}$ & $\begin{array}{l}\text { Oversee the overall activities of the project } \\
\text { Oversee the overall activities of the project } \\
\text { Responsible for obtaining necessary approvals }\end{array}$ \\
& Site Director & $\begin{array}{l}\text { Responsible for the activities within the project } \\
\text { site }\end{array}$ \\
& Project Director & Oversee the overall activities of the project \\
\hline Case B & $\begin{array}{l}\text { Chief Technical officer } \\
\text { Chief commercial officer }\end{array}$ & $\begin{array}{l}\text { Oversee the technical aspects of the project } \\
\text { Oversee the financial aspects of the project }\end{array}$ \\
& $\begin{array}{l}\text { Manager - Regulatory compliance } \\
\text { and local affairs }\end{array}$ & $\begin{array}{l}\text { Responsible for obtaining necessary approvals } \\
\text { Director (renewable energy) - } \\
\text { Sustainable Energy Authority } \\
\text { Project Consultant - Mega Polis } \\
\text { Assistant Director (Waste }\end{array}$ \\
$\begin{array}{l}\text { Management)- CEA ( } \\
\text { Director - Waste Management } \\
\text { Authority }\end{array}$ & $\begin{array}{l}\text { Responsible for sustainable energy } \\
\text { management projects }\end{array}$ \\
\end{tabular}

\section{CASE STUDY FINDINGS}

It became apparent from the case study findings that both cases have been following almost similar implementation process, which includes five phases such as 'Planning and feasibility (P\&F) phase (Phase I)', 'design phase (Phase II)', 'Construction phase (Phase III)', 'Commissioning phase (Phase IV) and finally 'Operation and maintenance (O\&M) phase (Phase V). The case study findings on stakeholders' involvement in WtE projects were discussed under each phase, which will be the basis for following discussion. 


\subsection{Stakeholder Involvement in Planning and Feasibility Phase}

This stage mainly deals with preparing project proposals and conducting project feasibility in terms of technical, environmental, economic, social, and legal. As revealed from both cases, Government, CEA, community, CEB, MC, funding organisations (i.e. financial institutes) are the key stakeholders who are generally engage in this phase. Because, these stakeholders could either be influential for the termination or continuation of WtE projects. Same as to them, project developer being the private party plays a major role in the project by handling entire implementation process. Although community belongs to the external stakeholder category, their influence on the success of the project is significant. For example, Project Director of Case A mentioned that, "earlier there were proposals for WtE plants but most of them were stopped from the beginning itself due to public protests as they are unaware about the real benefits of such WtE plants". As mentioned in above, both CEB and MC significantly influence to the success of the project because, the project will be succeeded only if CEB agrees to purchase generated electricity from WtE plant on a pre agreed unit price, and MCs' agrees to supply waste. Currently, both projects are typically large investments, which have been funded by project developer with the support of both local and financial institutes (refer Table 4). In addition, research organisations, civil contractors, Sri Lanka Land Development Corporation (SLRRDC), Urban Development Authority (UDA) and sustainable energy authority are the rest of the stakeholders who are involved in this phase (refer Table 4). These findings corroborated among both cases.

Table 4: Summary on responses on stakeholder involvement in planning and feasibility phase

\begin{tabular}{|c|c|}
\hline Stakeholder & Involvement/Interest \\
\hline \multirow[t]{2}{*}{ Project Developer } & $\begin{array}{l}\text { Cross-sectoral coordination (completing mandatory requirements } \\
\text { as requested by the government) }\end{array}$ \\
\hline & Invest money for the project \\
\hline \multirow[t]{2}{*}{ CEA } & Consider about the environmental feasibility of the project \\
\hline & Provide environmental policies and standards \\
\hline \multirow[t]{4}{*}{ Research institutes } & Conducting feasibility studies on available technologies \\
\hline & Conducting Environmental impact assessments \\
\hline & Guidance with elongated view of allocating resources \\
\hline & Assessing the economic feasibility of the project \\
\hline Community & Concern about the impact to them by this project \\
\hline \multirow[t]{2}{*}{ Funding organisations } & Providing necessary funds/loans for the project implementation \\
\hline & Feasibility of the project before the commencement \\
\hline \multirow[t]{2}{*}{ CEB } & Deciding the price, which they are purchasing a unit of electricity \\
\hline & Provides the PPA (Power Purchase Agreement) \\
\hline \multirow{2}{*}{$\begin{array}{l}\text { Municipal Council } \\
\text { (MC) }\end{array}$} & Interested about the effectivity of the project \\
\hline & $\begin{array}{l}\text { Provides waste supply agreement which is mandatory for the } \\
\text { project commencement. }\end{array}$ \\
\hline SLLRDC and UDA & Provides required land for the project implementation \\
\hline $\begin{array}{l}\text { Sustainable Energy } \\
\text { Authority }\end{array}$ & Considers $\mathrm{WtE}$ as a sustainable energy supplier \\
\hline
\end{tabular}




\begin{tabular}{ll}
\hline \multicolumn{1}{c}{ Stakeholder } & \multicolumn{1}{c}{ Involvement/Interest } \\
\hline $\begin{array}{l}\text { Government (Ministry } \\
\text { of Megapolis) }\end{array}$ & Implement legislations \\
& Concern about the health of public and environmental endangers \\
& $\begin{array}{l}\text { Provide infrastructural inputs and services } \\
\text { Interest about the benefits (sustainable energy generation, solution } \\
\text { for waste crisis) }\end{array}$ \\
\hline
\end{tabular}

\subsection{Stakeholder Involvement in Designing Phase}

In this phase, the entire project will be designed including the basic design and detailed design with the layouts of the plant and civil works construction plan. The EPC contractor is identified as the main internal stakeholder. It became evident from the case study findings that EPC is a team, which consists of specialists in the fields of Engineering, Procurement and Construction. The team was outsourced by the project developer in both cases. The main role of EPC contracting team is, providing of WtE technology to the project and expert knowledge on the design reviews. This was further explained by Chief Technical Officer of Case B as, "although our organisation has initiated the project, we do not have enough expertise knowledge and technology to continue the project, therefore, we have to take necessary support from the technology providers who have that specialised knowledge." In addition, there are other few stakeholders who are involved in the design stage as presented in Table 5. These stakeholders are common to both cases. Both cases have been getting the support from research institutions like universities in reviewing the design.

Table 5: Summary on responses on stakeholder involvement in design phase

\begin{tabular}{ll}
\hline \multicolumn{1}{c}{ Stakeholder } & \multicolumn{1}{c}{ Involvement/Interest } \\
\hline Project developer & Expect a successful design \\
EPC contractor & Provides the technical and constructions specifications of the plant \\
Research institutes & Provides consultation on technical drawings and specifications \\
CEA & Requires that design criterions in accordance with CEA regulations \\
\hline
\end{tabular}

\subsection{Stakeholder InVOLVEMENT in CONSTRUCTION PHASE}

In the construction phase, civil constructions and setting of the plant and machineries are the main activities identified through case study findings. As apparent from case study findings, both cases are still in the construction stage and have not started the WtE processes yet. In this phase, as revealed from both cases, EPC contractor, civil-contractor and project developer, government, CEA and community are the key stakeholders (refer Table 6). Same as to the design stage, EPC contractor is one of the key stakeholders involved in this stage too in addition to sub-contractors. At this stage, EPC contractor is responsible for the technical installations and provision of supervision for all the construction works while civil contractors play a major role in the construction works of the workshop structure. All the construction works have been monitored by the government to ensure that construction works are in accordance with building codes, relevant policies, and other relevant government regulations. Apart from those, the involvement of other stakeholders in this phase are summarised in Table 6. 
Table 6: Summary of responses on stakeholder involvement in construction phase

\begin{tabular}{ll}
\hline \multicolumn{1}{c}{ Stakeholder } & \multicolumn{1}{c}{ Involvement/Interest } \\
\hline Project Developer & $\begin{array}{l}\text { Concern whether the construction works are according the schedule and } \\
\text { payments are done by them }\end{array}$ \\
Civil-Contractor & $\begin{array}{l}\text { Construction of the project (civil works) } \\
\text { EPC Contractor }\end{array}$ \\
Government & $\begin{array}{l}\text { Eoniton of machinery and equipment } \\
\text { with the government requirements }\end{array}$ \\
CEA & $\begin{array}{l}\text { Monitoring and enforcement of environmental standards and regulations } \\
\text { related to construction }\end{array}$ \\
Community & Concern about the noise, dust and vibration traffic due to vehicles \\
\hline
\end{tabular}

\subsection{Stakeholder InVolvement in Commissioning Phase}

Although, two cases are still in the construction phase, in general practice, there are two types of commissions (i.e. cold commissioning and hot commissioning) in a WtE project as explained by all respondents. Although the activities to be done in each commissioning are common to both cases, duration of the commissioning period is different when comparing both cases. In Case A, the commissioning period of the plant will be 02 months and for Case B, it will be 04 months. Initially, the cold commissioning is done by operating the plant without MSW to make sure that systems of the plant are connected and working properly. Subsequently, the hot commissioning will be done using MSW as the fuel source without unit synchronizing but as a trail operation.

Same as to both design and construction stages, EPC contractor is the dominant stakeholder in this phase, because, all the responsibilities of both cold and hot commissioning are vested with EPC contactor. Although government has not played a direct role in this phase, they have been vigilant on commissioning activities to ensure that the project is success or not (refer Table 7).

Table 7: Summary of responses on stakeholder involvement in commissioning phase

\begin{tabular}{ll}
\hline \multicolumn{1}{c}{ Stakeholder } & \multicolumn{1}{c}{ Involvement/Interest } \\
\hline Project Developer & Concern about the functionality of the project \\
EPC Contractor & Make sure that the plant is according to the design \\
Government & Concern about the functionality of the plant \\
\hline
\end{tabular}

\subsection{STAKEHOLDER INVOLVEMENT IN O\&M PHASE}

Since both cases have not moved to this phase yet, practices done in this stage are identified from opinions of relevant stakeholders. As revealed from empirical research findings, O\&M stage includes all the activities from the supply of MSW to the plant and to the final activity of transmitting the generated energy to the grid. Moreover, it is mandatory to perform routine check-ups and scheduled maintenance. Project developer, plant operators, O\&M contractors, community, CEA, CEB, government, and $\mathrm{MC}$ are the stakeholders involved in this phase (refer Table 8). 
Table 8: Summary of responses on stakeholder involvement in O\&M phase

\begin{tabular}{|c|c|}
\hline Stakeholder & Involvement/Interest \\
\hline Project Developer & Functionality and the profitability of the project \\
\hline \multirow[t]{2}{*}{ Plant Operators } & Health and safety of workers while working in the site \\
\hline & Engage with the operations of the plant \\
\hline O\&M Contractors & Handling O\&M activities of the plant \\
\hline \multirow[t]{2}{*}{ CEA } & Concern about health risks and environmental problems \\
\hline & $\begin{array}{l}\text { Monitoring and enforcement of environmental standards and } \\
\text { regulations }\end{array}$ \\
\hline CEB & Continuous supply of electricity to the grid \\
\hline \multirow[t]{2}{*}{ Government } & $\begin{array}{l}\text { Concern about whether the plant is operating within the agreed } \\
\text { conditions }\end{array}$ \\
\hline & Concern about health risks and environmental problems \\
\hline Municipal Council & To supply of waste to the plant continuously \\
\hline \multirow[t]{4}{*}{ Community } & $\begin{array}{l}\text { Interested of such projects because of the creation of job } \\
\text { opportunities }\end{array}$ \\
\hline & $\begin{array}{l}\text { Expecting the success of the project as a solution to the prevailing } \\
\text { waste crisis }\end{array}$ \\
\hline & Concern about health risks \\
\hline & Source segregation should be done by the community \\
\hline
\end{tabular}

In this phase, electricity is generated and transmitted to the grid. According to the respondents, the community who live around the project are benefited in this stage through by jobs, which have been created in relation to O\&M works. Similarly, the rest of the whole community is also benefited through getting an effective solution to the prevailing waste crisis and it will exclude environmental externalities ensues from current MSWM practices, i.e. bad odour from landfills. Therefore, the community is attentive towards the effective and efficient operations of the plant. CEA is also playing a major role in the O\&M phase of a WtE project. This was explained by Assistant Manager renewable energy of Case A in detail manner as, "incineration of waste in mass scale would cause environmental endangers, hence it is mandatory to adhere to the regulations and standards of CEA on noise levels, emissions, leachate, fly ash and bottom ash productions". In addition, responsibilities on occupational health and safety are mainly vested with plant operators in this stage. In ensuring such responsibilities, plant operators are closely working with O\&M contractor. As per empirical research findings, being responsible on all O\&M maintenance activities, O\&M contractors are more dominant in this stage. As explained by the Managing Director of Case A, all such responsibilities are falls on them, once the agreement is signed with the project developer. Same as those stakeholders, involvement of the CEB and MC cannot be neglected in this stage. Respondents from both cases highlighted this fact. This is because, CEB is being the main electricity buyer of both projects (i.e. case A and case B), electricity will be purchased as agreed in PPA while MCs' will provide segregated MSW and they should exclude the pre-agreed waste like e-waste, hazardous waste. In this context, both projects will be continued only if CEB purchase electricity and MCs' supply MSW to the plant. 


\section{DISCUSSION}

A significant success factor for the implementation of any project is its stakeholders (refer Section 2), which was evident through empirical research findings as well (refer Section 4). Thus, it is vital to identify the relevant stakeholders and their involvement towards the project. Table 9 depicts the stakeholders' involvement in each phase, which was based on both literature and case study findings.

Table 9: Stakeholder involvement in implementation of WtE projects: At a glance

\begin{tabular}{|c|c|c|c|c|c|}
\hline \multirow[b]{2}{*}{ Stakeholder } & \multicolumn{5}{|c|}{ Project phases involved in } \\
\hline & $\begin{array}{l}\text { Phase } \\
\text { I }\end{array}$ & $\begin{array}{c}\text { Phase } \\
\text { II }\end{array}$ & $\begin{array}{c}\text { Phase } \\
\text { III }\end{array}$ & $\begin{array}{c}\text { Phase } \\
\text { IV }\end{array}$ & $\begin{array}{c}\text { Phase } \\
\text { V }\end{array}$ \\
\hline \multicolumn{6}{|l|}{ Project Developer } \\
\hline \multicolumn{6}{|l|}{ EPC Contractor } \\
\hline \multicolumn{6}{|c|}{ Government $^{*}$ (Ministry of Megapolis) } \\
\hline \multicolumn{6}{|l|}{ Community (Public, media) ${ }^{*}$} \\
\hline \multicolumn{6}{|l|}{ Research Institutes $^{*}$} \\
\hline \multicolumn{6}{|l|}{$\mathrm{CEB}^{*}$} \\
\hline \multicolumn{6}{|l|}{$\mathrm{CEA}^{*}$} \\
\hline \multicolumn{6}{|c|}{ Funding Organisations (Financial institutions) ${ }^{*}$} \\
\hline \multicolumn{6}{|l|}{ Municipal Council (MC) } \\
\hline \multicolumn{6}{|l|}{ SLLRDC and UDA } \\
\hline \multicolumn{6}{|l|}{ Sustainable Energy authority } \\
\hline \multicolumn{6}{|l|}{ Plant Operators } \\
\hline \multicolumn{6}{|l|}{ O\&M Contractors } \\
\hline Civil Contractor & & & & & \\
\hline
\end{tabular}

Phase I: Planning and feasibility phase

Phase II: Design phase

Phase III: Construction phase

Phase IV: Commissioning phase

Phase V: O\&M phase

Note: "Findings identified from both literature review and case study findings. Other findings are identified only from cases.

By reviewing the existing literature, seven (07) key stakeholders were identified such as government, industrial experts, community, private organisations, environmental regulators, collection and transportation companies and energy producers (refer Section 2.2). These literature findings were in general and not specific to the Sri Lankan context. However, these stakeholders are almost similar to the Sri Lankan context as well according to case study findings (refer Section 4). Case study findings further disclosed eleven (11) additional important stakeholders, such as Project Developer, CEB, EPC contractor, O\&M contractor, civil-contractor, plant operators, $\mathrm{MC}$, funding organisations, SLLRDC, UDA and sustainable energy authority (refer Section 4). These stakeholders are more dominant throughout the lifecycle of a WtE project. However, their involvement 
has not been discussed in the literature yet. It was acknowledged that only CEB is playing the role of energy producer, which was identified through the literature (The World Bank 1999; Soltani et al. 2015) and project developer being the private organisation who is handling the project. Moreover, the study done by Soltani et al. (2015), identified government and municipalities as one stakeholder, since both parties having interconnections to each other. However, case study findings were contrasted to the study by Soltani et al. (2015), wherein Sri Lankan context they were identified as two separate stakeholders. Although, the World Bank (1999) identified collection and transportation companies as one of the key stakeholders in a WtE project, it was not the same when it comes to the Sri Lankan context. This is because, currently, in Sri Lanka, collection of MSW are done by the municipalities itself. Further, although existing literature has not been stressed the necessity of partaking of an EPC contractor yet, the involvement of same stakeholder has made a significant impact to the Sri Lankan WtE projects as per empirical research findings. This is because, Sri Lanka being a developing country, currently lacks with required expertise technical knowledge on WtE projects. The existing situation has created the need for outsourcing EPC service from overseas. Same as to researchers such as Joseph (2006); Collaborative Working Group (2016); Pandey et al. (2016), case study findings too disclosed the influence of community on the successful implementation of a $\mathrm{WtE}$ project, because their perceptions towards the project are indirectly causing the project success or failure.

\section{CONCLUSIONS}

So far in Sri Lanka, only two WtE projects have been implemented and four projects were adjourned due to many issues arose. As identified, one of the main reasons for failures of these projects was the lesser understanding of the involvement of stakeholders in terms of their roles, which they need to perform when carrying out the project. Thus, this research intended to investigate the stakeholders' involvement in the successful implementation of WtE projects in Sri Lankan context. The study disclosed fourteen (14) stakeholders who are involved throughout the whole lifecycle of a WtE project together to make the project a success. Among them, community, CEA, CEB, government, municipal council, project developers and EPC contractors are identified as the most imperative stakeholders throughout the WtE implementation process in Sri Lankan context with the nature of their unique role. Understanding of the role of these stakeholders will enable the future WtE industry of Sri Lanka to coordinate them properly by saving project time and cost. Overall, the knowledge generated through this research can be used by respective industry practitioners in Sri Lanka in implementing future WtE projects successfully.

\section{REFERENCES}

Breeze, P., 2018. The Economics of Energy from Waste. Energy from Waste, pp.83-87.

Collaborative Working Group., 2016. Waste to Energy Rapid Assessment Tool. St. Gallen: Swiss Resource Center and Consultancies for Development

Contreras, F., Hanaki, K., Aramaki, T. and Connors, S., 2008. Application of analytical hierarchy process to analyze stakeholders' preferences for municipal solid waste management plans, Boston, USA. Resources, Conservation and Recycling, 52, pp.979-991.

Energy Information Administration [online] Waste-to-Energy (Municipal Solid Waste) - Energy Explained, Your Guide to Understanding Energy. Available from: Eia.gov: 
https://www.eia.gov/energyexplained/index.cfm/data/index.cfm?page=biomass_waste_to_energy [Accessed $11^{\text {th }}$ January 2017).

Hoornweg, D. and Bhada, P., 2012. What a Waste: A Global Review of Solid Waste Management. Washington: Urban Development \& Local Government Unit - World Bank

Joseph, K., 2006. Stakeholder participation for sustainable waste management. Habitat International, 30 , pp.863-871.

Keunecke, M., 2016. Energy from waste -Improvements in energy efficiency. Waste Management, 54, pp.1-2.

Kothari, R., Tyagi, V., and Pathak, A. 2010. Waste-to-energy: A way from renewable energy sources to sustainable development. Renewable and Sustainable Energy Reviews, 14(9), pp.3164-3170.

Li, T., Ng, S. and Skitmore, M. 2013. Evaluating stakeholder satisfaction during public participation in major infrastructure and construction projects. Automation in Construction, 29, pp.123-135.

Moya, D., Aldás, C., López, G. and Kaparaju, P., 2017. Municipal solid waste as a valuable renewable energy resource: a worldwide opportunity of energy recovery by using Waste-To-Energy Technologies. Energy Procedia, 134, pp.286-295.

Ogawa, H., 2000. Sustainable solid waste management in developing countries. $7^{\text {th }}$ ISWA International Congress and Exhibition. Kuala Lumpur, Malaysia: World Health Organization.

Ouda, O. and Cekirge, H., 2013. Roadmap for Development of Waste-to Energy Facility in Saudi Arabia. American Journal of Environmental Engineering, 3(6), pp.267-272.

Palanivel , T. M. and Sulaiman, H., 2014. Generation and Composition of Municipal Solid Waste (MSW) in Muscat, Sultanate of Oman. APCBEE Procedia, pp.96-102.

Pandey, B., Vyas, S., Pandey, M. and Gaur, A., 2016. MSW to energy conversion methodology as physical, thermal, and biological methods. Current Science Perspectives, 2(2), pp.39-44.

Priyalal, G., 2017. Energy Generation Using MSW: Case of Waste to Energy Mega Projects in Sri Lanka. (pp. 1-91). Colombo: University of Moratuwa

Ramachandra, T., Bharath, H., Kulkarni, G. and Han, S., 2018. Municipal solid waste: Generation, composition and GHG emissions in Bangalore, India. Renewable and Sustainable Energy Reviews, 82, pp.1122-1136.

Rawlins, J., Beyer, J., Lampreia , J. and Tumiwa , F., 2014. Waste to energy in Indonesia [online]. London: Carbon Trust., Available on: https://www.carbontrust.com/media/512147/ctc831-waste-to-energy-inindonesia.pdf [Acessed 18 ${ }^{\text {th }}$ November 2017].

Schiffer, H.-W., Westhuizen, Z., Radu, C., Ibeanu, N., Marshall , J., Hoornweg, D., Itodo, I., 2016. World Energy Resources Waste to Energy. World Energy Council.

Soltani, A., Hewage, K., Reza, B. and Sadiq, R., 2015. Multiple stakeholders in multi-criteria decisionmaking in the context of MSW Management: A review. Waste Management, 35, pp.318-328.

The World Bank., 1999. Technical Guidance Report: Municipal Solid Waste Incineration. Washington, DC: The International Bank for Reconstruction and Development

Themelis, N. and Ulloa, P., 2007. Methane generation in landfills. Renewable Energy, 32, pp.1243-1257.

Yin, R., 2014. Case Study Research: Design and Methods, $5^{\text {th }}$ ed. Thousand Oaks, CA: SAGE International Publications 